\title{
EDITORIAL
}

\section{ANZAM's new journal}

\section{Ken Parry}

Editor, Journal of Management \& Organization
W elcome to the first edition of the Journal of Management \& Organization (JMO).

Steve Kempster reports on research into how people in senior executive leadership positions have learnt leadership throughout their careers. He used the methodology of critical realism to uncover and explain the metaphor of 'apprenticeship' to assist with our sense-making of this important aspect of managerial life.

Fernando and Jackson researched religionbased workplace spirituality and its impact upon the decision-making of senior business leaders. They found that decision-making was facilitated by traditional management techniques plus, in difficult moments, by a higher-order construct associated with a transcendent reality. Religion plays a significant role.

Neil McAdam reports on a large world-wide research project. He found that stress moves us away from creative, collaborative and ambiguitybased brain styles toward performance-driven and control-oriented brain styles. In the Australasian tertiary academic sector, I can see precisely this phenomenon in action over the last 10 years. Our challenge is to maintain our creativity and not to fall into control-oriented styles. This is precisely the point made by Bill English in his article.

Bill English is Shadow Education Minister in New Zealand and a former Education Minister. In his article we can see that New Zealand has experienced tertiary educational reforms similar to those that Australia is in the process of implementing now. It remains to be seen whether Australian policy-makers have learned from the New
Zealand experience. Personally, I doubt it. English advocates a simpler model of oversight of the sector, with less costly and potentially unmanageable control mechanisms. In Australia we continue to see policy models characterised by complexity, cost, and control mechanisms that are difficult to maintain. He makes the point that incentive is better for our sector than control. This maxim is reasonably obvious to most of us, but it seems to be discarded too readily by our policy-makers and many university managers. In small economies, like Australia and New Zealand, control is easier to implement than incentive, but it is less effective. The challenge for us all is to unleash the huge potential that we have in our tertiary academic sector with policies based on incentive; and with management practices based on efficiency and not expensive administration.

\section{The future for JMO}

In this editorial, I have directed my comments mainly to my colleagues in New Zealand and Australia. This situation will not remain for much longer. JMO will quickly have a global reach in the scholarship that is presented. This is not the Australian and New Zealand Journal of Management \& Organization. Nor is it the Asia-Pacific Journal of Management \& Organization. It is THE Journal of Management \& Organization.

I see our journal no longer being reliant on ANZAM conference papers as the main source of quality submissions. With our new international editorial board we have the potential to make the refereeing process even more constructive and 
valuable. We also have the prospect of attracting more quality submissions from around the world.

We have managed to generate quick turnaround on submissions over the past two years, and we plan for this to be a strength of JMO. We also have the plan to offer two special editions and two general editions each year. Special editions are widely seen as a sound vehicle for producing cohesive publications that are of considerable scholarly value to a readership. The second edition of Volume 12 is the special edition on 'emotions and coping with conflict in the workplace', edited by Peter Jordan and Ashlea Troth. I look forward to receiving other offers to edit special editions for JMO.

My thanks go to the people who have helped with JANZAM over the past two years. These people include the members of the final editorial board of JANZAM. I also thank our colleagues who have reviewed submissions throughout 2005. Their names appear below in alphabetical order.

\section{JANZAM Reviewers - 2005}

Simon Albrecht

Anona Armstrong

Kim Boal

Ingrid Bonn

Brad Bowden

Sara Branch

David Brock

John Brocklesby

Paula Brough

Ken Butcher

Colin Campbell-Hunt

Ray Cooksey

Trish Corner

Urs Daellenbach

Carol Dalglish

Richard Dunford

Mario Fernando
Jason Fitzsimmons

Jody Fry

Jeremy Galbreath

Ray Gordon

Steve Grover

Chrys Gunasekara

Railton Hill

Gary Howat

Bill Hutchinson

Brad Jackson

David Lamond

Gael McDonald

Tui McKeown

Ian McLoughlin

Jonathan Matheny

Janny Maddern

Peter Miller
Jonathan Pratt

John Rice

Ian Roos

Paul Ryder

Chris Selvarajah

Clive Smallman

Cathy Sheehan

Amrik Sohal

Winsome St John

Stephen Teo

Ashlea Troth

Tim Turpin

Terry Waters-Marsh

Retha Wiesner

Angus Young

\section{Online Reviewer Application Form}

The Journal of Management \& Organization (ISSN 1833 3672) welcomes participation by experts as reviewers.

If you would like to join the reviewer panel of the journal, please enter your contact details and areas of expertise into the online form on the journal website: www.jmanorg.com

We shall confirm your details and look forward to consulting you.

eContent Management Pty Ltd, PO Box 1027, Maleny OLD 4552, Australia

Tel.: +61-7-5435-2900; Fax. +61-7-5435-2911

www.e-contentmanagement.com 